\title{
Annual Report on the External Quality Assessment Scheme for Immunoassay Tests in Korea (2015)
}

\author{
Hyon-Suk Kim, \\ Young Lan Kim, and \\ Jung Eun Shim, as \\ the Immunoassay \\ Subcommittee, Korean \\ Association of External \\ Quality Assessment \\ Services \\ Department of Laboratory \\ Medicine, Severance \\ Hospital, Yonsei University \\ College of Medicine, Seoul, \\ Korea
}

Two trials of external quality assessment were performed in 2015, with 13 test items grouped into four test categories. The first trial materials were sent on May 19, 2015 and the second trial was performed on November 9, 2015 with 13 items including tumor markers, thyroid hormones, cardiac marker troponin (troponin $\mathrm{T}$ or troponin I), and procalcitonin (PCT) as biomarkers by immunoassay methods. The bone marker, carboxy-terminal collagen crosslinks (CTX) was replaced by procalcitonin since 2014, because a limited number of institutions performed assays with CTX. External quality surveys of 13 immunoassay test items with 16 control materials were conducted, as scheduled. In total, 13 control materials were used, which consisted of six tumor markers, namely alpha-fetoprotein (AFP), carcinoembryonic antigen (CEA), carcinoma antigen (CA) 125, carbohydrate antigen (CA) 19-9, human chorionic gonadotrophin (HCG), and prostate specific antigen (PSA). In addition to tumor markers, 5 thyroid markers, namely thyroid hormone (T)3, T4, thyroid stimulating hormone (TSH), free T4, and thyroglobulin (TG) were included. Furthermore, troponin, as a cardiac marker, and procalcitonin, as a new biomarker, have been adopted since 2014. Five home-made pooled sera and 3 commercial control sera were used as survey materials. MAS Tri-point Liquimmune level 3 (Medical Analysis Systems Inc., USA) was used for thyroid hormones. Procalcitonin and troponin control materials were from Elecsys Precis Control Varia and Elecsys Precis Control Troponin (Roche, Germany), respectively. The number of laboratories participating in the external quality assessment for Immunoassay Subcommittee was 719 institutions in the first trial survey (response rate 98.7\%) and 730 institutions in the second survey (94.9\%). The test items most frequently used in immunoassays were TSH $(93.2 \%, 93.1 \%)$, free T4 $(90.3 \%, 90.2 \%)$, and AFP $(89.4 \%$, $89.0 \%)$, whereas recently adopted biomarkers were less frequently used: troponin I (36.6\%, $37.1 \%)$, procalcitonin $(24.1 \%, 26.7 \%)$, and thyroglobulin $(10.3 \%, 10.7 \%)$. The quality of the laboratories participating in the survey seems to be continuously improving, according to their peer group results.

(J Lab Med Qual Assur 2016;38:194-213)

Key Words: Immunoassay, Quality assurance, External quality assessment, Surveys, Tumor marker, Thyroid marker, Cardiac marker, Troponin, Procalcitonin

\section{서론}

2015년도에도 전년도에 이어 2회의 외부정도관리 신빙도 조사사업을 실시하였다[1]. 각 회당 8개씩의 관리물질들을 냉 장택배로 우송하였고, 검사종목은 종양표지자 6종, 갑상선 표지자 5종 및, 전년도에 이어 올해도 면역단백종목에서 새 로운 표지자로 thyroglobulin과 심장표지자 troponin을 포 함하였고, 작년에 골흡수표지자 carboxy-terminal collagen crosslinks (CTX) 대신 새로운 급성기 바이오표지자 종목으 로 도입한 procalcitonin을 올해도 대상으로 하였다[2-4]. 종 목 선정은 외부기관의 자료를 통하여 현재 우리나라 임상검사 실에서 immunoassay 방법으로 가장 활발히 검사가 실시되 고 있는 종목들을 선택하였다. 즉 종목 수로 총 13 종의 면역 측정법 검사종목을 대상으로 하였다. 대상기관은 지난해까지 Immunoassay 분과 사업에 참여해 온 기관들과 올해 신규 가 입기관, 그리고 새로 참여의사를 밝혀 온 우리 대한임상검사정 


\section{Journal of LABORATORY MEDICINE and QUALITY ASSURANCE}

Hyon-Suk Kim et al • External Quality Assessment for Immunoassay Tests

도관리협회 회원기관들을 대상으로 하였다.

2015년도 신빙도조사사업에 사용한 관리물질은 각 기관당 1 년에 총 16 개였는데, 원칙적으로 원가절감을 위하여 주관기 관에서 자가제조하였다. 즉 주관기관에서 각 종목별로 검사 후 남은 양성 및 음성 혈청을 수집하여 pooling해서 제조하였 다. 각 종목별로 임상검사실 결과치를 살펴보고 높은 결과치를 보이는 검체와 낮은 결과치를 보이는 검체들을 각각 수집하여 레벨별로 pooling하였다[3-5]. 이렇게 자가제조한 관리물질 을 포함하여 각 회당 8 개씩 총 16 개의 관리물질을 사용하였는 데, 결과치가 높은 검체를 얻기가 어려웠던 갑상선호르몬 종목 을 포함하는 관리물질과 새로 도입한 심장표지자 troponin의 고농도 관리물질은 상품화된 제품을 구입하여 사용하였다. 즉 2015년 한 해 동안 2 회의 외부정도관리 신빙도조사를 총 16 종 의 관리물질을 가지고 13 종목에 대해 실시하였다.

\section{재료 및 방법}

\section{1. 관리물질}

외부정도관리 신빙도조사를 위한 관리물질은 2 회의 검체 발 송 시에 각 8 종씩, 총 16 종을 사용하였다. 1 회와 2 회째 모두 갑 상선호르몬검사용 관리물질과 새로운 바이오마커인 troponin 종목의 고농도 관리물질은 상품화된 제품을 구입하여 사용하 였는데, 높은 결과치를 보이는 혈청을 구하기 어려웠기 때문 이었고, 그 외의 관리물질은 자가제조하는 것을 원칙으로 하 였다. 제조방법은 환자 검사 및 건강검진쎈터에서 의뢰된 혈청 들을 대상으로 각 종목마다 결과치를 검토하여 각 종목에 따 라 level별로 수집하였다가 pooling하여 제조하였다. 자가제조 한 관리물질과 상품화된 갑상선호르몬 고농도용 물질(MAS Tri-point Liquimmune level 3; Medical Analysis Systems Inc., Camarillo, CA, USA), 그리고 2년 전부터 새로 추가 된 troponin은 Elecsys Precis Control Troponin (Roche, Mannheim, Germany)을 구매하여 개별포장하여 냉장택배로 배송하였다. 각 검사종목별로 해당 검체를 사용하여 검사하도 록 각 검체별로 검사종목을 지정하였다.

즉 총 2 회의 외부정도관리 신빙도조사사업에 각 8 종씩의 관 리물질을 우송하였고, 종양표지자, 갑상선호르몬과 새로운 바 이오마커인 procalcitonin과 심장표지자검사를 종목별로 각 검 체를 지정하여 해당 검사를 실시하도록 하였다. 검체 발송은 1 차는 5월 19일에, 2차는 11월 9일에 발송하였다.

\section{2. 검사종목}

종양표지자 종목으로 alpha-fetoprotein (AFP), carcino- embryonic antigen, human chorionic gonadotrophin (HCG, $\beta-\mathrm{HCG}$ ), prostate specific antigen (PSA) 및 carcinoma antigen 125 (CA 125)와 carbohydrate antigen 19-9 등 6종 목을 대상으로 하였으며, 갑상선 기능검사 종목으로 thyroid hormone (T)3, T4, thyroid stimulating hormone 및 free T4 외에 2013년부터 새로 추가된 thyroglobulin을 대상 으로 하였다. 그리고 이때 2013년부터 혈청 면역단백검사 를 immunoglobulin G ( IgG), immunoglobulin A ( IgA), immunoglobulin $\mathrm{M}$ (IgM), complement (C)3 및 C4 등 5종 대신 새로 도입된 심장표지자 종목(troponin $\mathrm{T} /$ troponin I)과 CTX를 그리고 2014년부터는 CTX 대신 procalcitonin에 대하 여 외부신빙도조사를 실시하였다.

\section{3. 결과의 분석 및 보고방법}

검사결과의 분석 및 보고방법은 평균, 표준편차, 변이계수 등으로 분석하였으며, 참여기관에서 사용하고 있는 방법과 장 비에 따라 각 기기별로 분류하여 결과를 분석하였다. 협회에서 전산화를 추진하여 완성되었기에 우리 분과의 외부신빙도조 사 결과 입력은 물론, 전체 방법과 기기별 통계, 그리고 각 기 관의 결과지까지도 인터넷을 이용하여 입력은 물론, 결과지 출 력까지도 우리 협회 홈페이지에서 가능하게 되었다.

$\mathrm{AFP}$ 의 경우 검사결과 보고 단위로 농도 및 국제 단위 의 두 가지가 있는데, 현재는 $\mathrm{ng} / \mathrm{mL}$ 의 단위가 더 널리 사 용되고 있는 추세임을 감안하여 이미 2010년부터는 $\mathrm{ng} / \mathrm{mL}$ 의 단위로 모두 환산하여 분석하고 있다. 각 기관에서 사 용하는 immunoassay 검사방법으로서 reversed passive hemagglutination법 같은 정성이나 반정량검사를 사용하는 기관들도 아주 적은 수이지만 있었는데, 양성과 음성으로만 결 과를 보고하였기 때문에 통계처리대상에서는 제외하였다.

그리고 갑상선호르몬 검사종목들은 각 기관마다 보고하는 단위와 참고치가 달라서 복잡하였다. 이들 결과치는 통일하여 입력하도록 하였고 그 결과를 통계 처리하였다. 그런데 각 병 원마다 아직도 장비에 따라 보고 단위가 다른 것을 통일하지 않거나 계산결과가 이상한 결과치가 발견되기도 하였다. 그 결 과를 일괄 통계 처리하기 전에 이상하다고 생각되는 경우에는 다시 각 기관에 전화를 걸어 확인하였는데, 일일이 해당 기관 에 전화를 하여 확인하였고 그래도 확인하기 어려운 경우도 있 었다. 


\section{Journal of LABORATORY MEDICINE and QUALITY ASSURANCE}

\section{Hyon-Suk Kim et al • External Quality Assessment for Immunoassay Tests}

Table 1. Schema of external quality assessment of immunoassay subcommittee in 2015

\begin{tabular}{lcccc}
\hline & No. of laboratories invited & Participating laboratories (\%) & Date for procurement of sera & Date of results \\
\hline 1st trial & 719 & $710(98.7)$ & 2015.5 .19$. & 2015.7 .3$. \\
2nd trial & 730 & $693(94.9)$ & 2015.11 .9$. & 2015.12 .31$. \\
\hline
\end{tabular}

Second trial response rate was decreased due to the laboratory consolidation policy of the centers belong to Korea Association of Health Promotion.

Table 2. List of laboratories participating in the assessment of immunoassay tests in 2015

\begin{tabular}{ccc}
\hline \multirow{2}{*}{ Test marker } & \multicolumn{2}{c}{ Participating laboratories } \\
\cline { 2 - 3 } & 1st trial (\%) & 2nd trial (\%) \\
\hline Tumor markers & $635(89.4)$ & $617(89.0)$ \\
Thyroid markers & $662(93.2)$ & $645(93.1)$ \\
Cardiac markers & & $87(12.6)$ \\
Troponin T & $78(10.9)$ & $257(37.1)$ \\
Troponin I & $260(36.6)$ & $185(26.7)$ \\
New biomarker & & $693(100.0)$ \\
Procalcitonin & $171(24.1)$ & 730 \\
$\begin{array}{c}\text { Results received } \\
\text { Total no. of } \\
\text { institutions invited }\end{array}$ & $710(100.0)$ & \\
\hline
\end{tabular}

\section{결과}

\section{1. 참여기관}

외부정도관리사업을 위한 검체 발송은 2015년 5월 현재 정 도관리협회에 등록된 기관 중 지난해까지 본 분과사업에 참여 하였거나 또는 이번에 새로 참여의사를 밝힌 기관과 신규 가입 한 기관을 본부 홈페이지에서 내려 받아 대상기관을 파악하였 으며, 1 차에는 719 기관에, 2 차에는 730 기관에 검체를 발송하 였다.

2015년도에 외부정도관리사업 결과, 회신기관 수는 1 차 710 기관, 2차 693기관이었다(Table 1). 전체 참여기관 수는 2005 년도 2 차 305 기관에 비하여 현재 2015년에는 2 배 이상으로 참 여기관이 많이 증가하였다.

참여한 기관들에서 실시하는 각각의 검사종목별로 살펴보 면 종양표지자 종목에는 1차와 2차에 각각 635기관과 617기 관, 갑상선호르몬 종목에는 662기관과 645기관, 그리고 새로 운 종목에는 종목에 따라서 troponin-T/troponin-I는 1차와 2 차 각각 $78 / 260$ 기관, $87 / 257$ 기관에서 검사결과를 회신하였다 (Table 2). 또 procalcitonin의 경우 1 차 171 기관, 2 차 185 기관 에서 회신하였다.
Table 3. List of currently participating laboratories testing the immunoassay items in 2015

\begin{tabular}{|c|c|c|}
\hline & 1st trial & 2nd trial \\
\hline \multicolumn{3}{|l|}{ Tumor markers } \\
\hline Alpha-fetoprotein & $635(89.44)$ & $617(89.03)$ \\
\hline Carcinoembryonic antigen & $554(78.03)$ & $527(76.05)$ \\
\hline Carcinoma antigen 125 & $441(62.11)$ & $412(59.45)$ \\
\hline Carbohydrate antigen 19-9 & $482(67.89)$ & $454(65.51)$ \\
\hline Prostate specific antigen & $543(76.48)$ & $513(74.03)$ \\
\hline HCG & $155(21.83)$ & $155(22.37)$ \\
\hline$\beta-\mathrm{HCG}$ & $7(0.99)$ & $7(1.01)$ \\
\hline \multicolumn{3}{|l|}{ Thyroid markers } \\
\hline T3 & $571(80.42)$ & $550(79.37)$ \\
\hline $\mathrm{T} 4$ & $133(18.73)$ & $124(17.89)$ \\
\hline Free $\mathrm{T} 4$ & $641(90.28)$ & $625(90.19)$ \\
\hline Thyroid stimulating hormone & $662(93.24)$ & $645(93.07)$ \\
\hline Thyroglobulin & $73(10.28)$ & $74(10.68)$ \\
\hline \multicolumn{3}{|l|}{ Cardiac markers } \\
\hline Troponin $\mathrm{T}$ & 78 (10.99) & $87(12.55)$ \\
\hline Troponin I & $260(36.62)$ & $257(37.09)$ \\
\hline \multicolumn{3}{|l|}{ New biomarker } \\
\hline Procalcitonin & $171(24.08)$ & $185(26.70)$ \\
\hline Results received & $710(100.00)$ & $693(100.00)$ \\
\hline Total no. of institutions invited & 719 & 730 \\
\hline
\end{tabular}

Values are presented as number (\%).

Abbreviations: HCG, human chorionic gonadotrophin; T, thyroid hormone.

\section{2. 검사종목별 회신율}

Immunoassay 정도관리 검사종목별 회신기관 수는 Table 3 에 표시하였다. 전년도에 비하여 대상기관 수와 회신기관 수 는 꾸준히 늘어나고 있음을 알 수 있다. 특히 10년간 별로 실 시하는 기관이 늘지 않은 혈청면역단백 종목들 대신에 새로운 표지자를 시도하였는데 전년도에 이어 심장표지자검사는 참 여기관의 $47.6 \%$ (1차)와 $49.6 \%$ 이상의 기관에서 실시하고 있 었다. 또한 동일 기종을 사용하는 기관들 간에는 편차가 크지 않았다. 그러나 다른 종류의 장비 간에는 다른 종목과 마찬가 


\section{Journal of LABORATORY MEDICINE and QUALITY ASSURANCE}

\section{Hyon-Suk Kim et al • External Quality Assessment for Immunoassay Tests}

Table 4. Control materials used for immunoassay external quality assessment in 2015

\begin{tabular}{|c|c|c|c|}
\hline Test marker & Test item & 1st trial & 2nd trial \\
\hline \multirow[t]{7}{*}{ Tumor markers } & Alpha-fetoprotein & Specimen no. 1, 2 (15-IA-1, 2) & Specimen no. 9, 10 (15-IA-9, 10) \\
\hline & Carcinoembryonic antigen & & \\
\hline & Carcinoma antigen 125 & & \\
\hline & Carbohydrate antigen 19-9 & & \\
\hline & HCG & & \\
\hline & $\beta$-HCG & & \\
\hline & PSA & Specimen no. $3^{*}, 4\left(15-\mathrm{IA}-3^{*}, 4\right)$ & Specimen no. $11^{\star}, 12\left(15\right.$-IA- $\left.11^{\star}, 12\right)$ \\
\hline \multirow[t]{5}{*}{ Thyroid markers } & $\mathrm{T} 3$ & & \\
\hline & $\mathrm{T} 4$ & & \\
\hline & Free $\mathrm{T} 4$ & & \\
\hline & Thyroid stimulating hormone & & \\
\hline & Thyroglobulin & & \\
\hline \multirow[t]{2}{*}{ Cardiac marker } & Troponin $\mathrm{T}$ & Specimen no. $7^{\star}, 8^{\star}\left(15-\mathrm{IA}-7^{\star}, 8^{\star}\right)$ & Specimen no. 15, $16(15$-IA-15, 16) \\
\hline & Troponin I & & \\
\hline New biomarker & Procalcitonin & Specimen no. 5, 6 (15-IA-5, 6) & Specimen no. $13,14(15-\mathrm{IA}-13,14)$ \\
\hline
\end{tabular}

Abbreviations: HCG, human chorionic gonadotrophin; T, thyroid hormone.

${ }^{*}$ Commercial sera: others were pooled sera prepared by Immunoassay Subcommittee.

지로 면역자동분석기의 특성대로 결과치에는 차이가 있음을 알 수 있었다. 2015년도 외부정도관리에 사용한 관리물질을 Table 4에 정리하였다.

\section{Immunoassay 검사방법 및 장비의 사용 현황}

2015년도 Immunoassay 정도관리사업에 참여한 기관들 의 각 검사종목을 검사방법 및 기기별로 구분하여 Tables 5-19에 정리하였다. Enzyme immunoassay 장비들에서 chemiluminiscence immunoassay 장비들로 거의 전환되어, 현재 참여하고 있는 임상검사실들에서 주로 사용되고 있는 것 은 chemiluminiscence immunoassay를 이용하는 자동면역장 비들이었다.

\section{4. 정도관리물질}

올해 정도관리에 사용한 상품화된 정도관리물질(MAS Tripoint Liquimmune level 3; Medical Analysis Systems Inc.) 은 갑상선호르몬검사에 사용하도록 지정하였고, 나머지 다른 관리물질은 환자와 건강인의 pooled sera를 level별로 모아 냉 동보관하였다가 자가제조한 것이었다. 각 검사종목별로 환자 들의 검사결과를 확인하고 혈청을 pooling하여 각 level을 제 조하였다. 단, 높은 농도의 검체를 대량 구하기 어려운 갑상선 호르몬 종목과 새로운 표지자로 선정한 심장표지자검사용은 상품화된 물질을 구입하여 제조하였다. 일부 level 검체들은
정상인의 혈청을 가지고 희석하여 제조하였다.

\section{5. 분과 워크숍}

2015년 협회 추계학술대회와 전체 통합워크숍이 있었는데 우리 Immunoassay 분과에서 필요한 내용을 선택하여 '면역 측정검사의 정도관리'라는 제목으로 세 명의 연자가 강의로 참 여하였다.

\section{고찰}

최근에 Immunoassay와 관련된 분야에서는 검사방법 이 민감도와 특이도가 높은 화학발광면역법과 이에 따른 여 러 가지 유사한 검사방법들인 electro chemiluminescence immunoassay 등의 방법들이 도입되었다. 즉 immunoassay 검사 중 많은 종류의 검사가 기존의 radioimmunoassay 방법 에서부터 enzyme immunoassay로, 다시 chemiluminescence immunoassay로 빠르게 대치되었다[6-10]. 이는 immunoassay검사에 도입되는 면역효소법 및 화학발광법이 이제는 방 사성 동위원소검사법보다 더 높은 민감도와 특이도를 가지게 되었으며 유효기간이 더 길다는 등 장점이 많고 자동화가 가능 하여 최근 임상검사실의 요구를 충족할 수 있기 때문으로 생각 된다[11].

종양표지자 검사종목들은 원래 스크리닝 목적으로 사용하는 


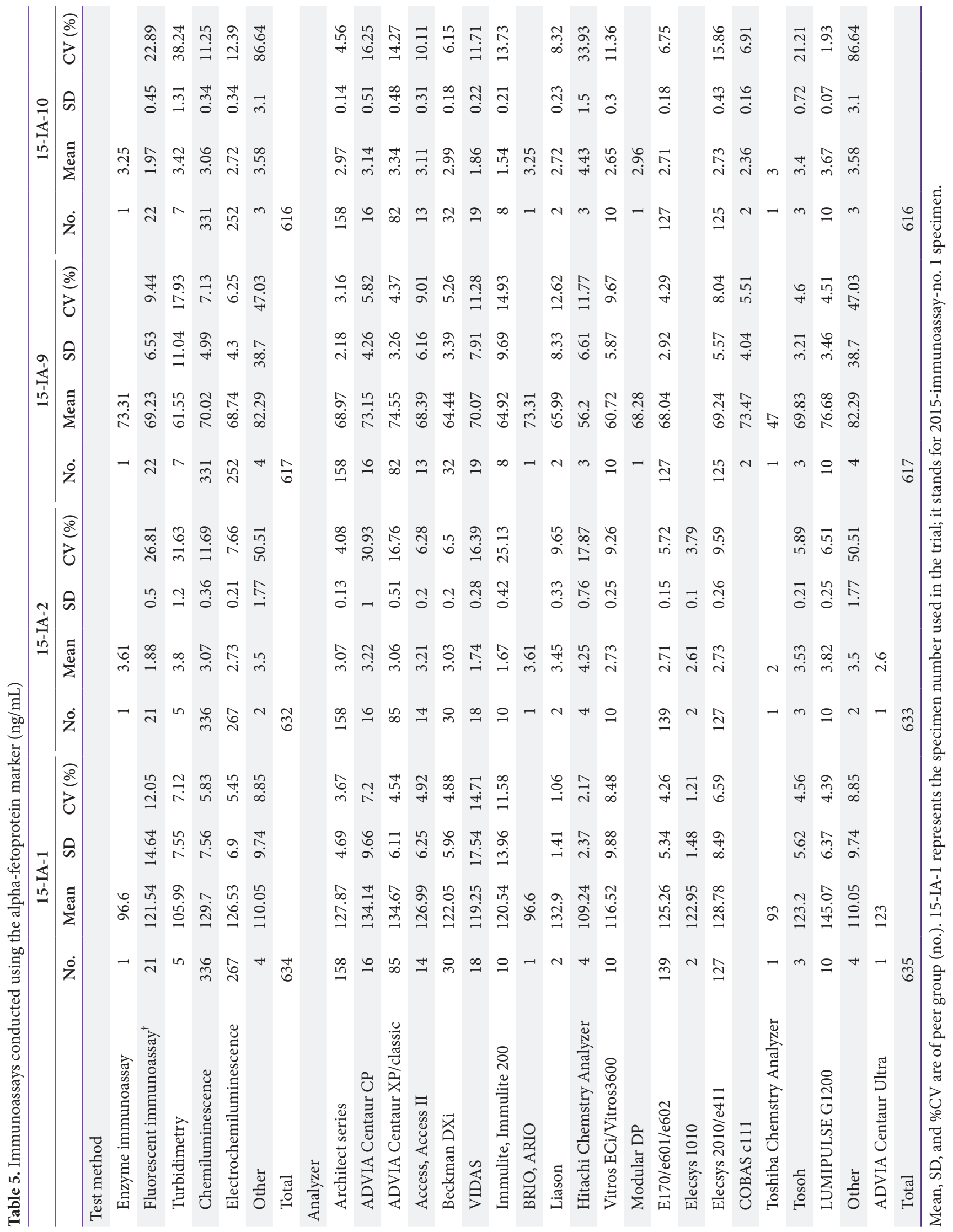




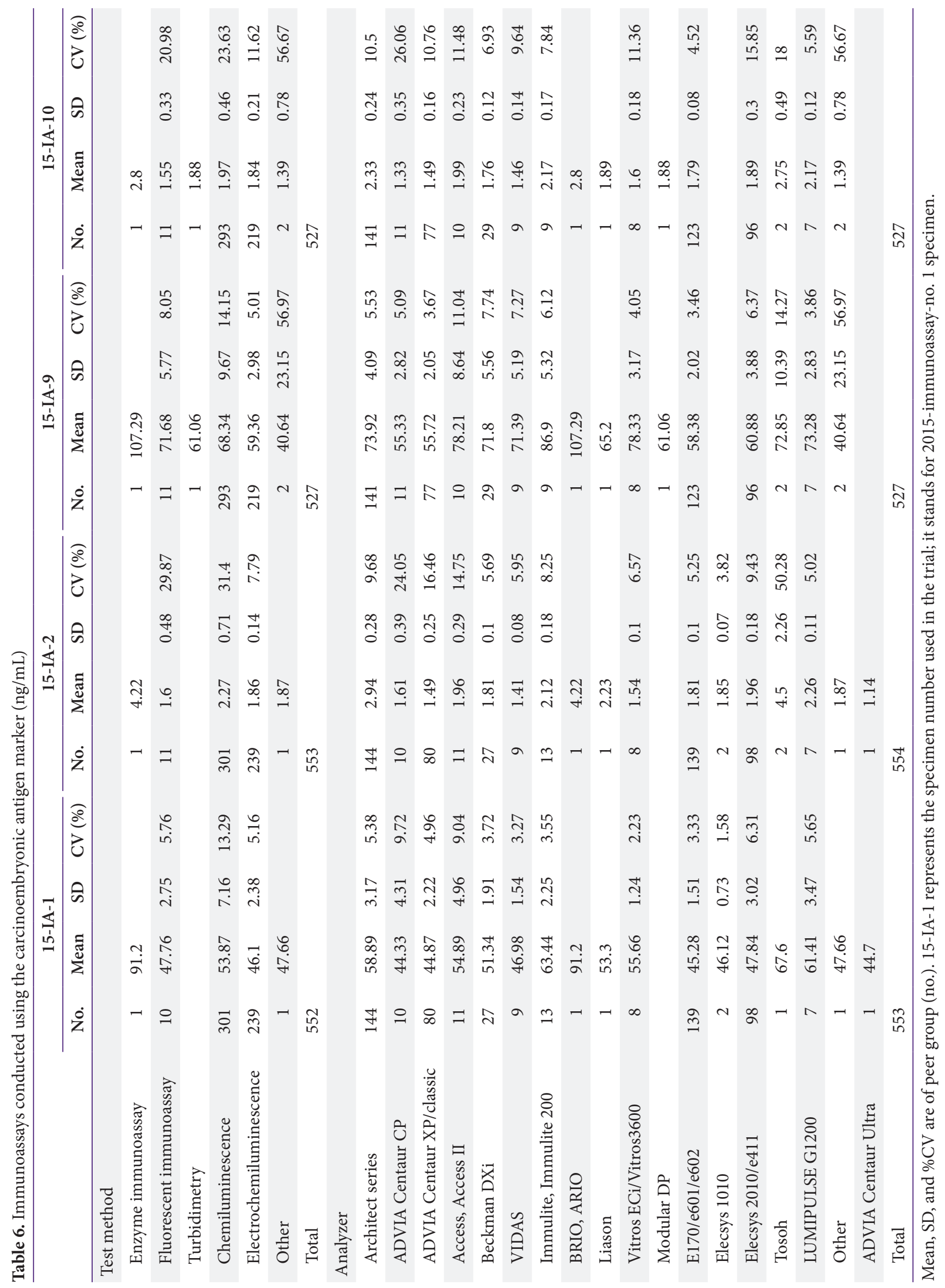


Hyon-Suk Kim et al • External Quality Assessment for Immunoassay Tests

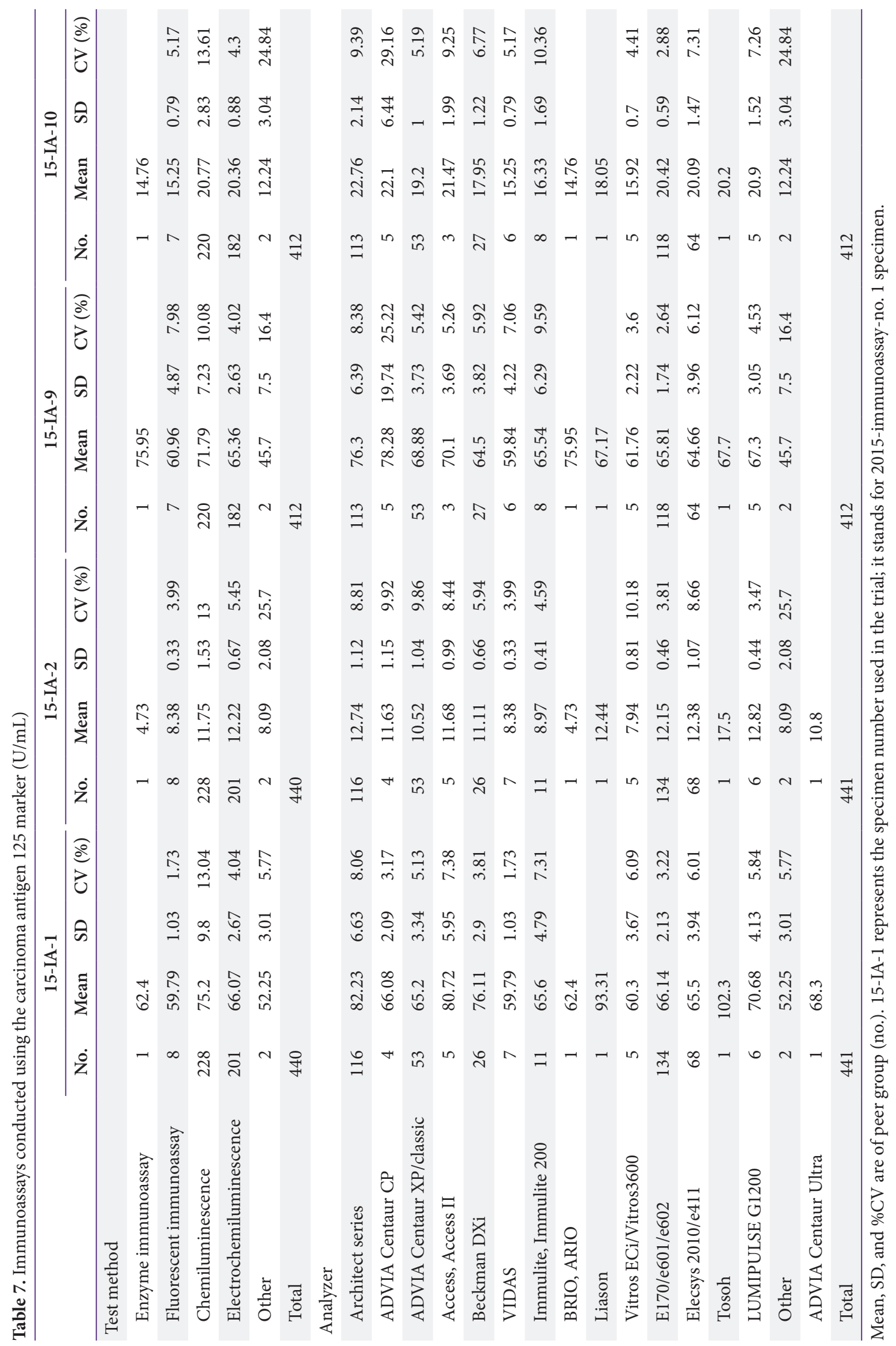




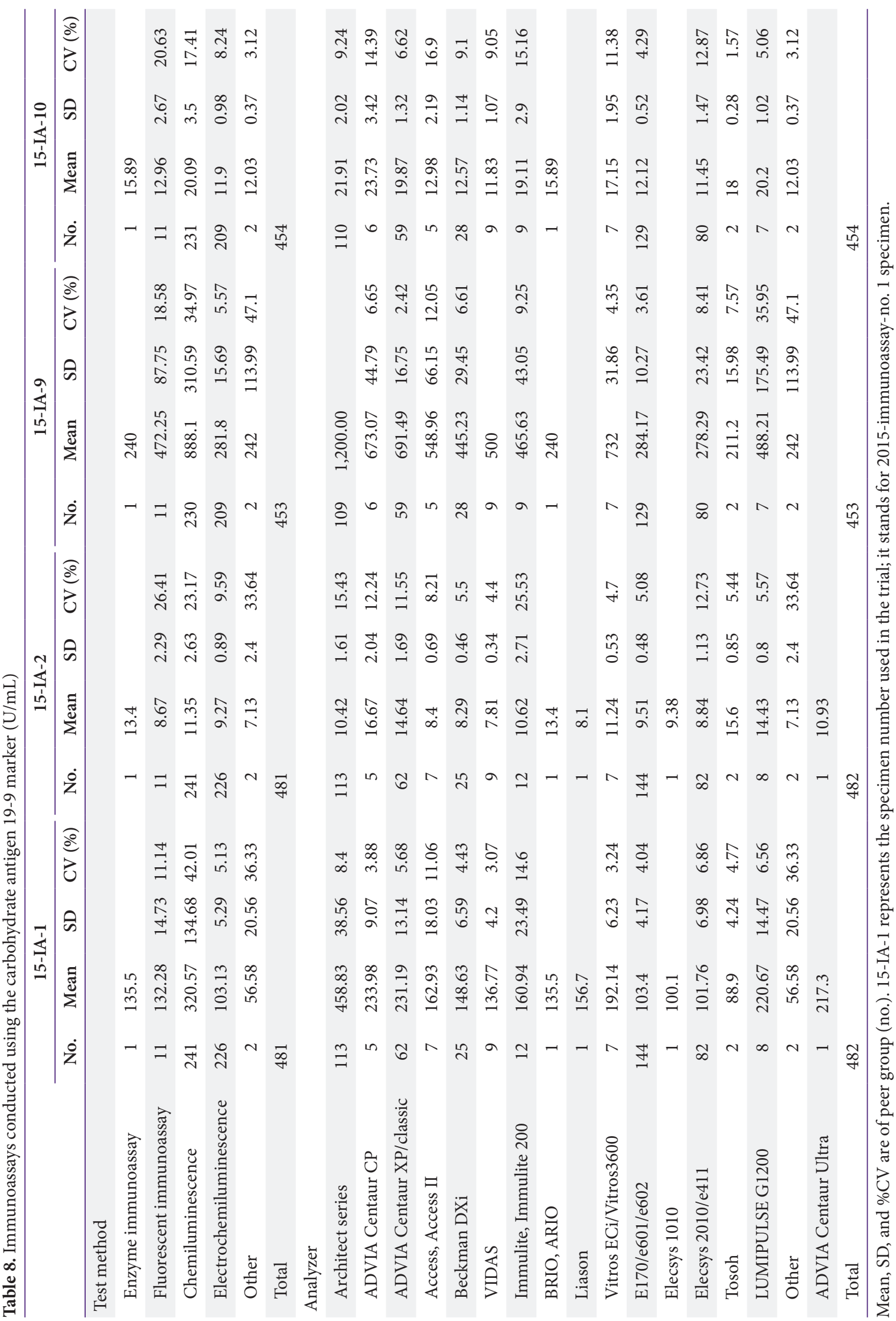




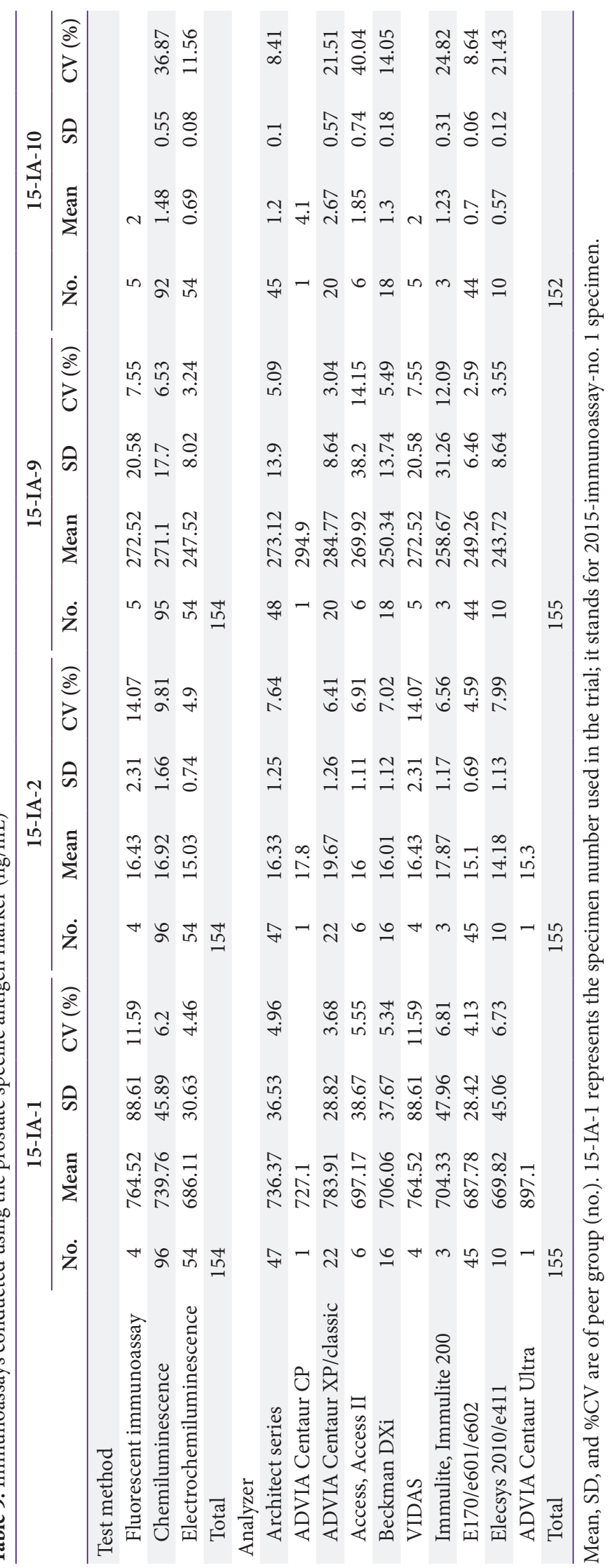

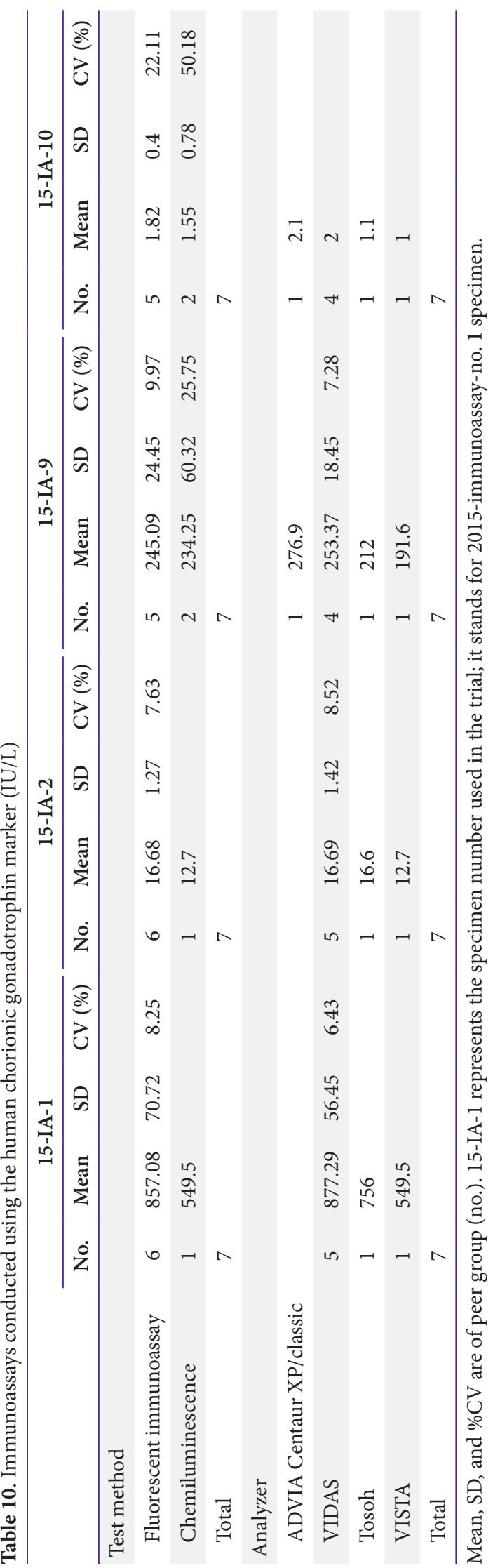




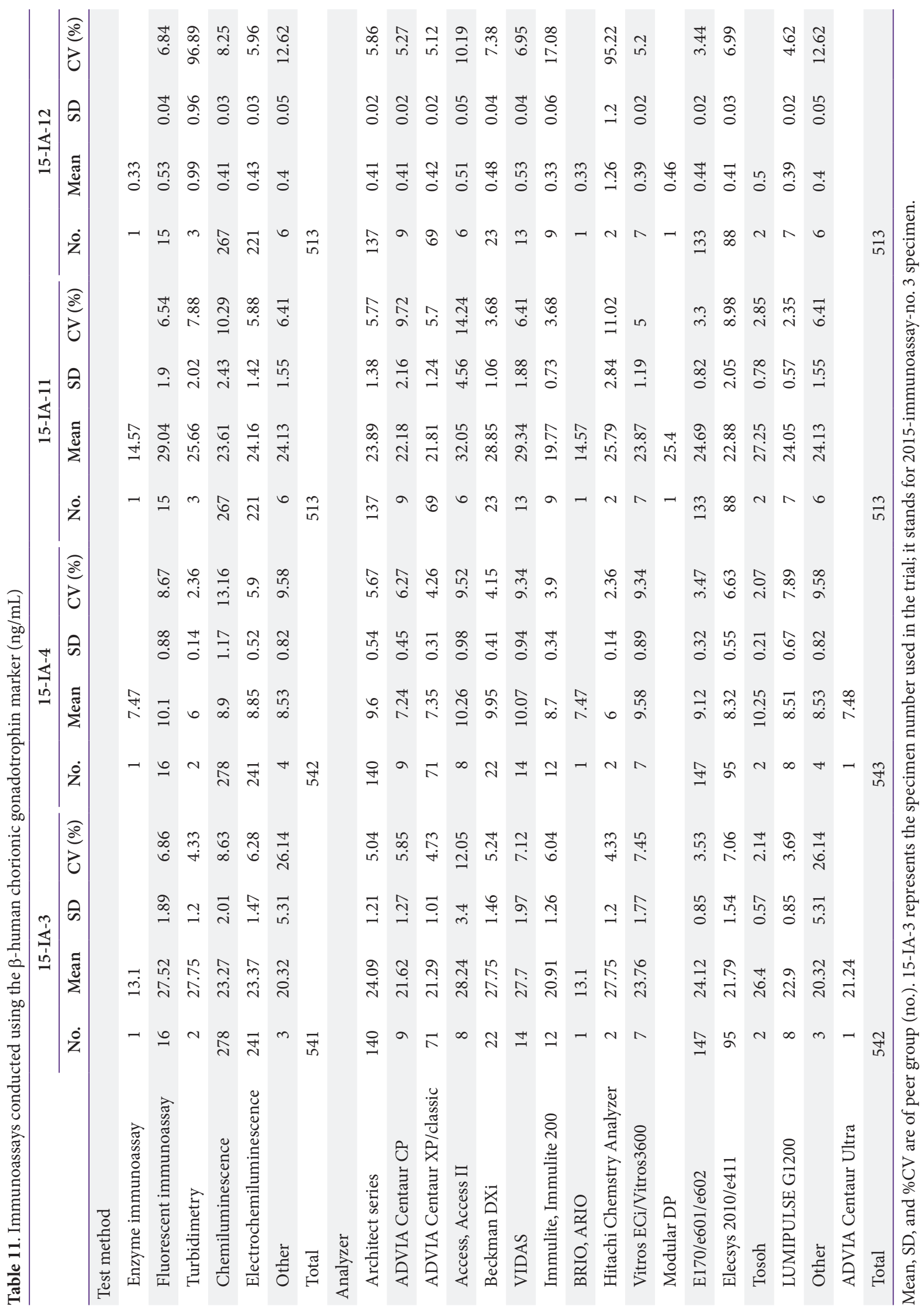




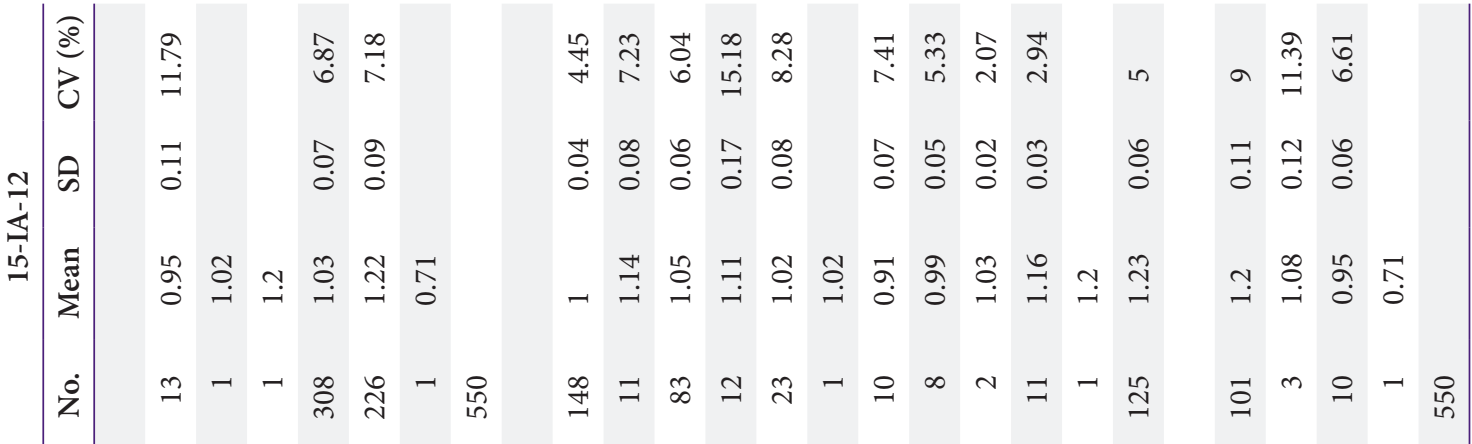

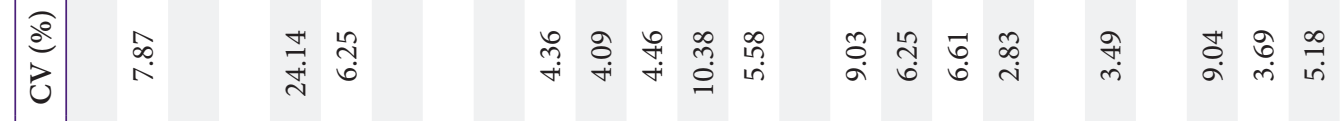

ची की

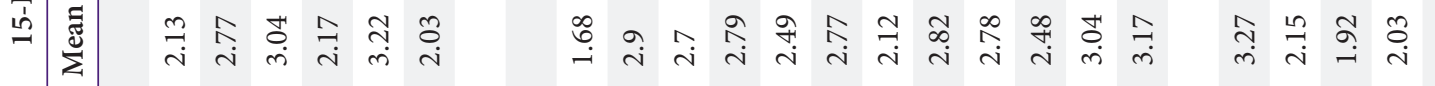

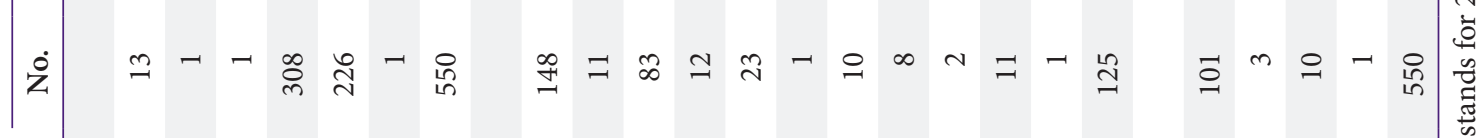

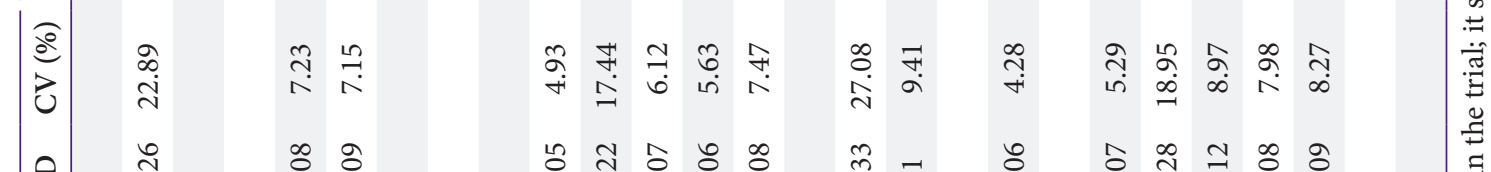

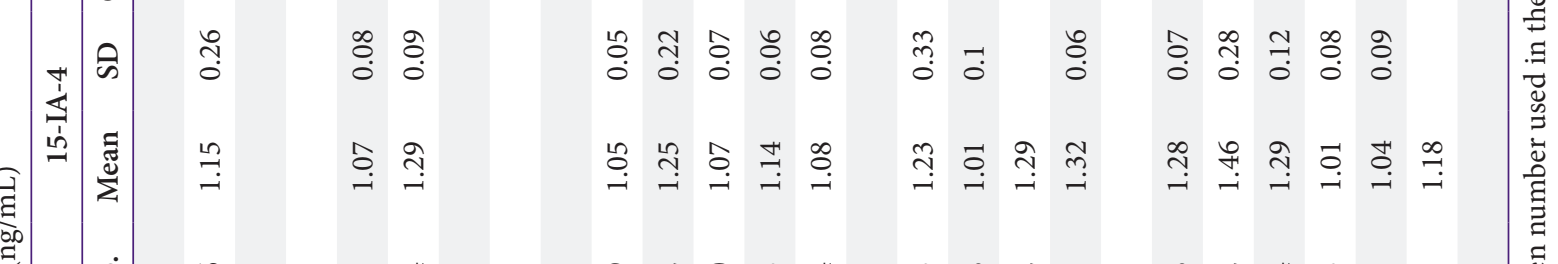

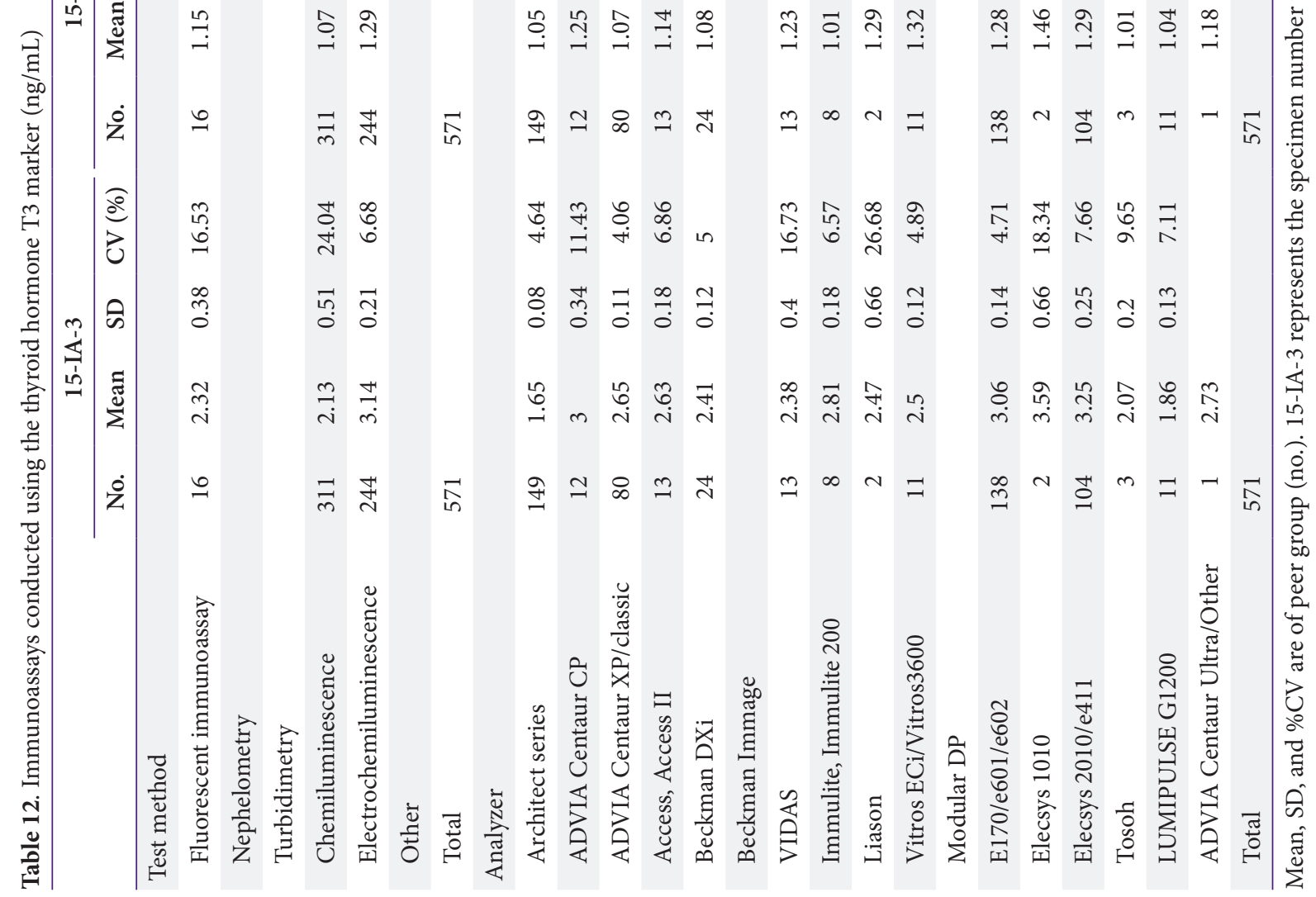




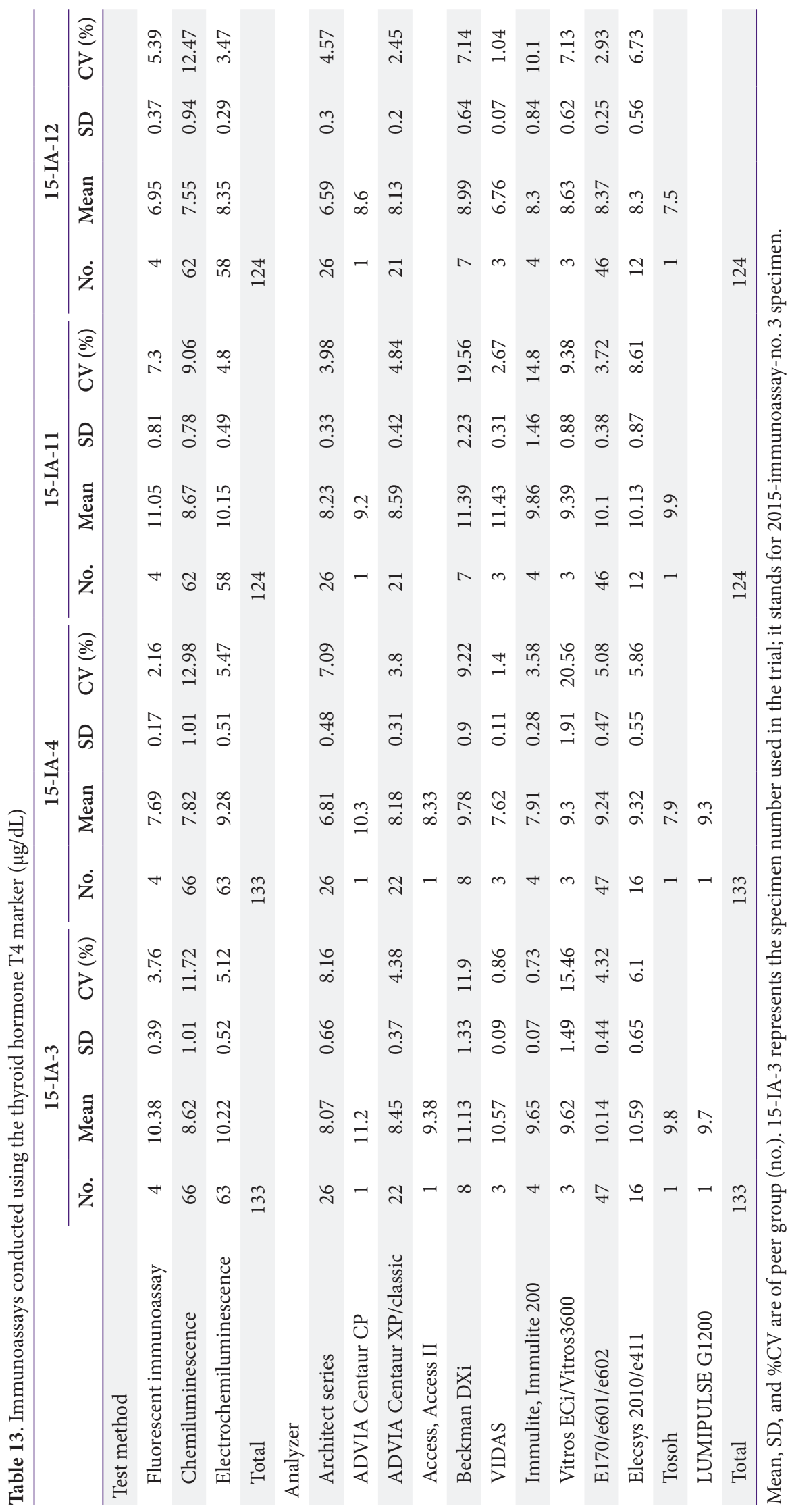




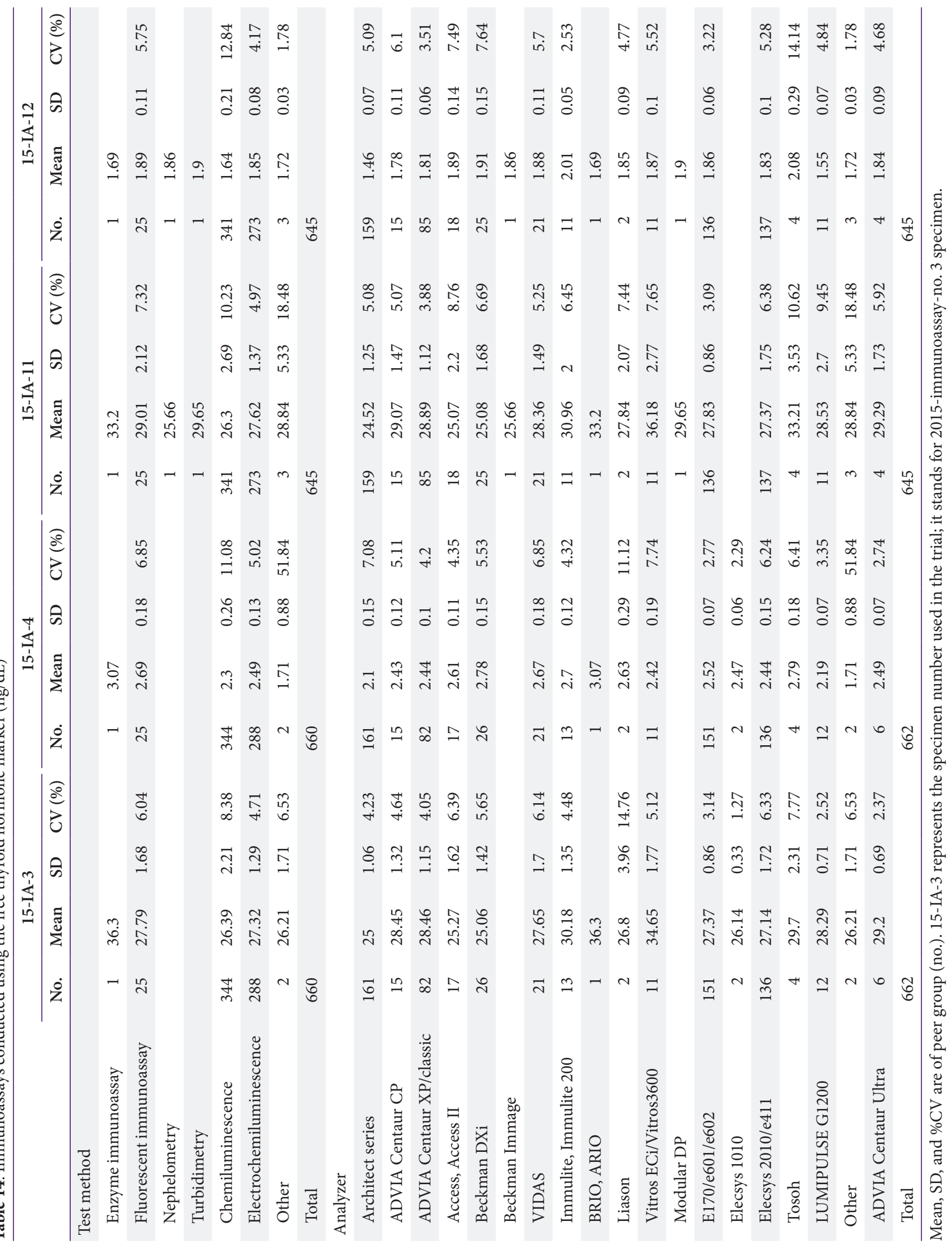




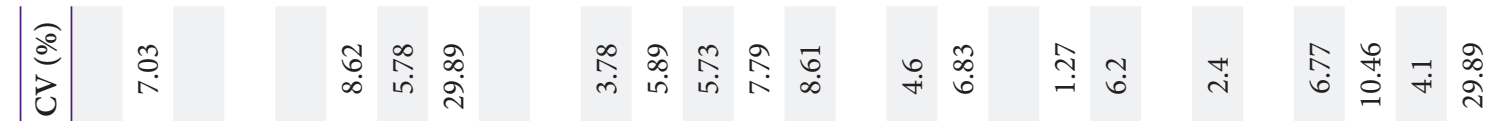

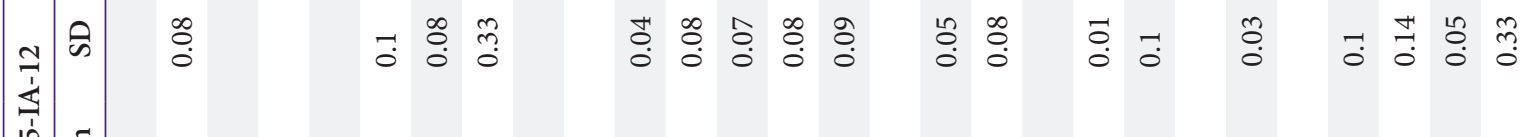

ம்

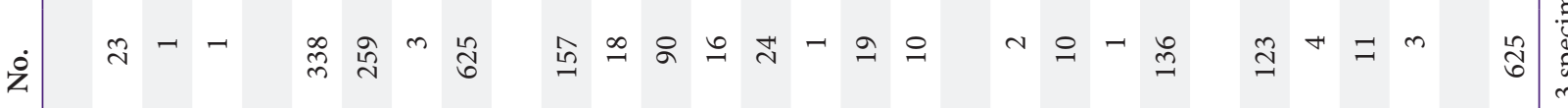

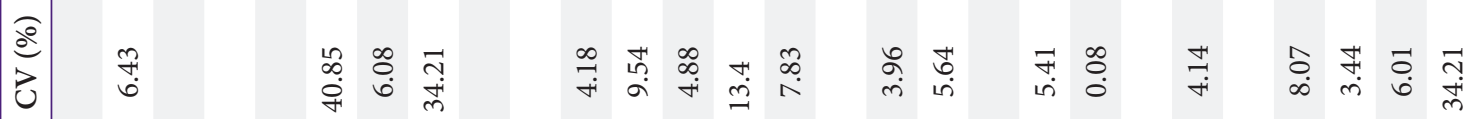

चक ते त्रे

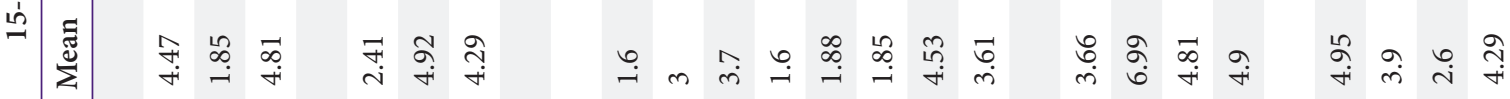

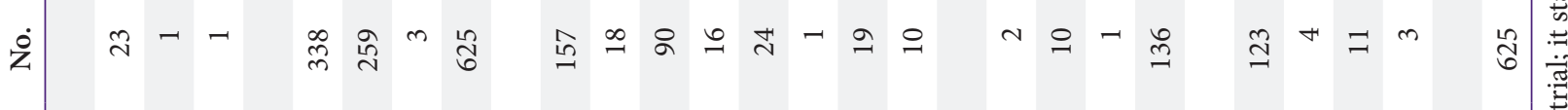

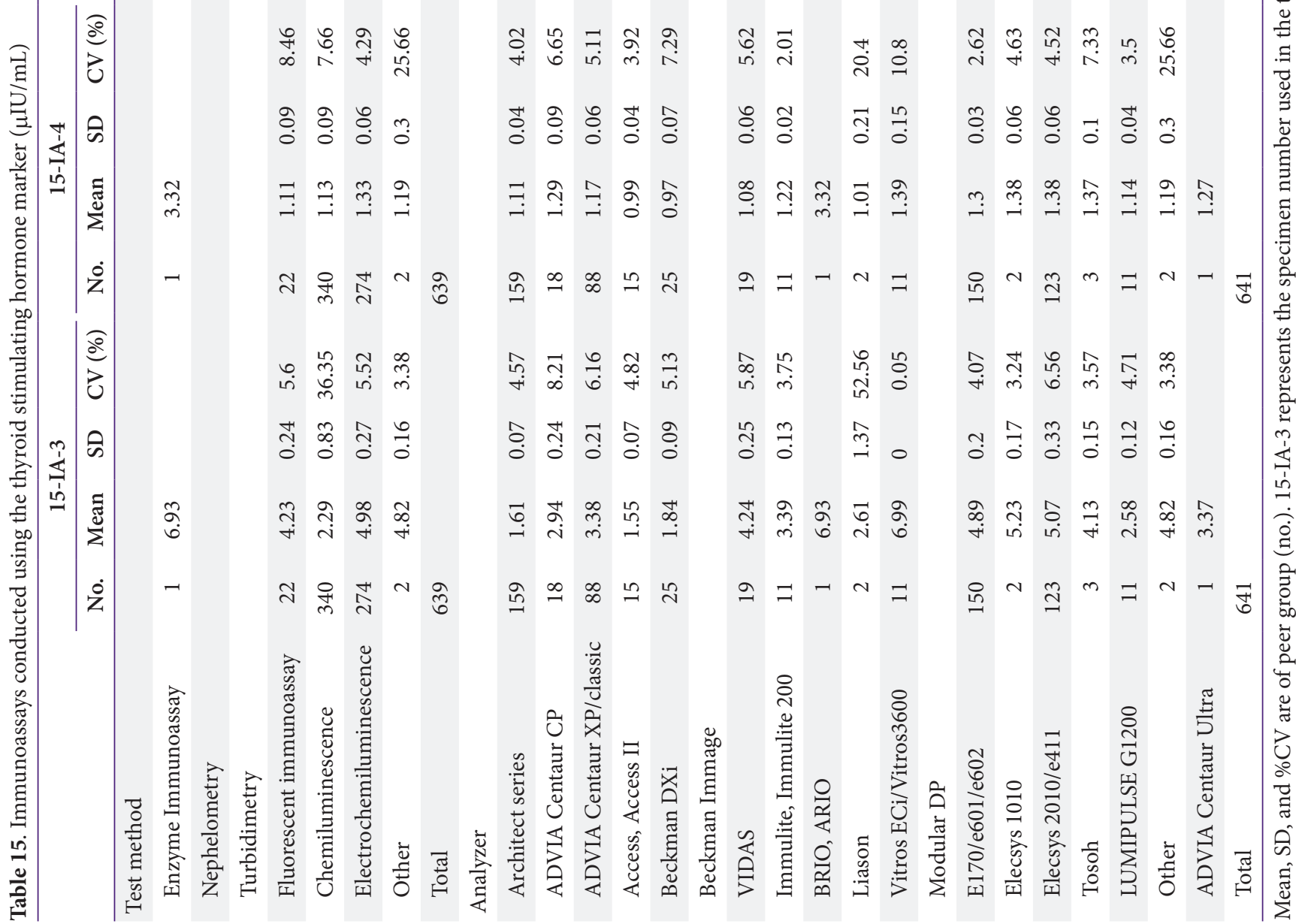




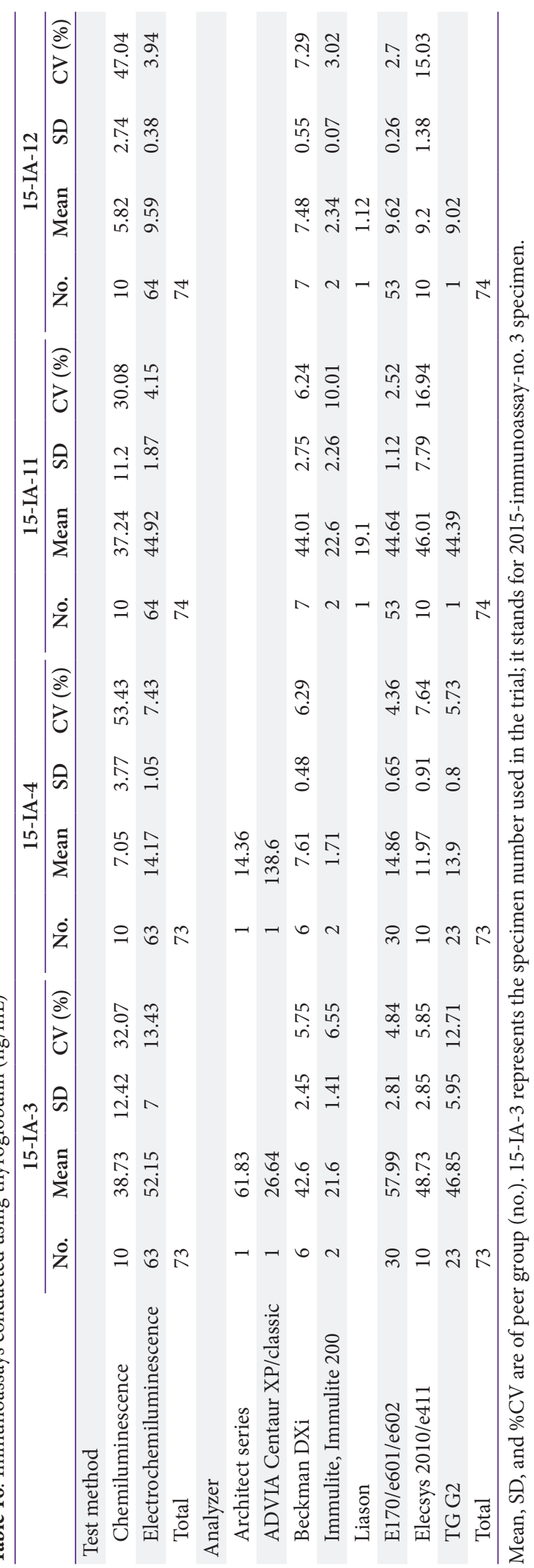

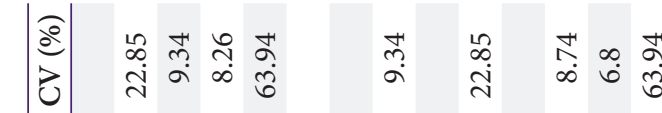

स की

เิ

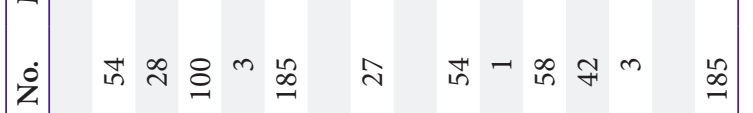

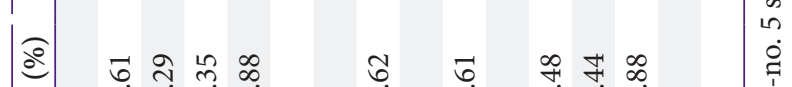

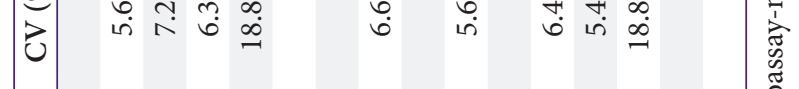

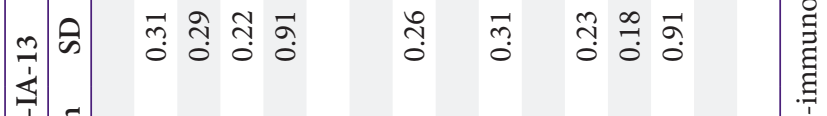

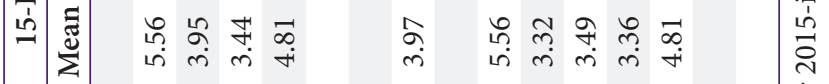
$\dot{\vec{z}}$ แ艹 ग) ப) की की 苟

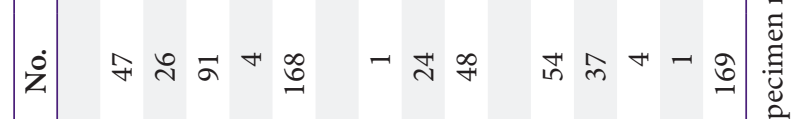

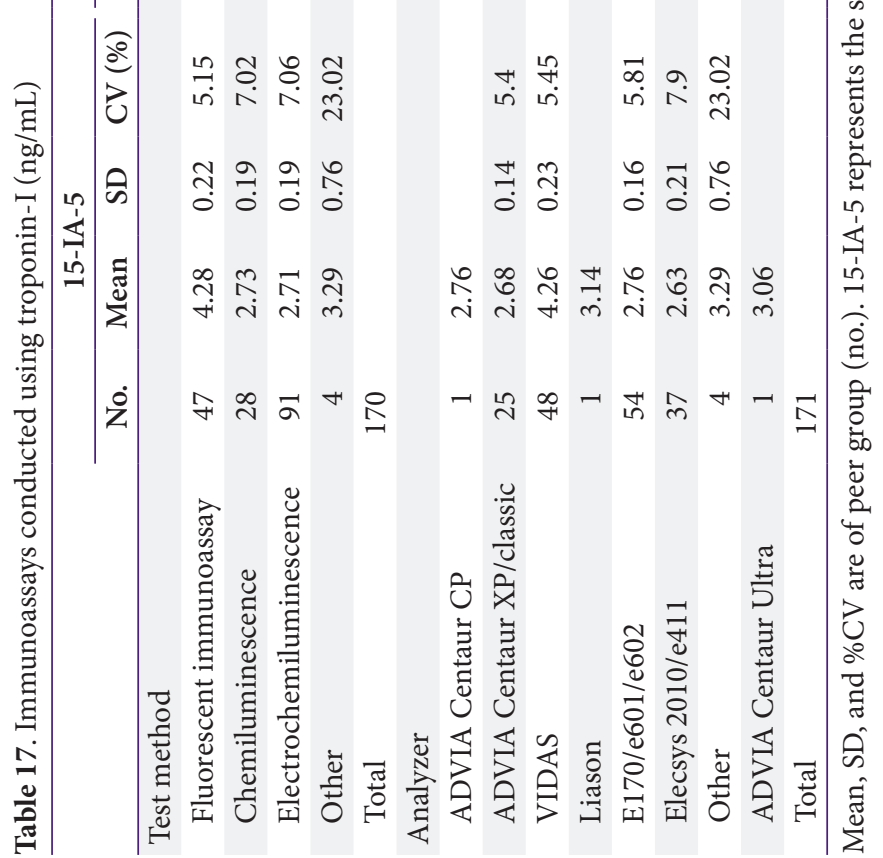


Journal of LABORATORY MEDICINE and QUALITY ASSURANCE

Hyon-Suk Kim et al • External Quality Assessment for Immunoassay Tests

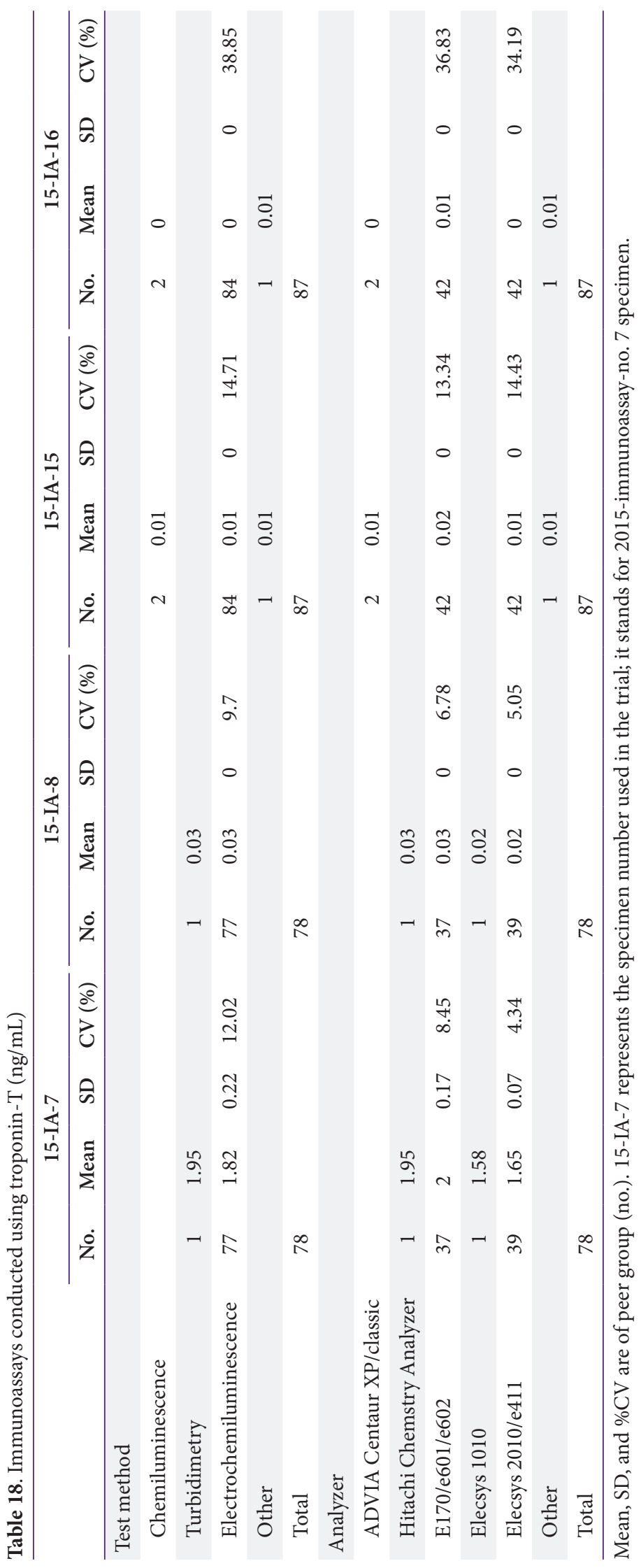




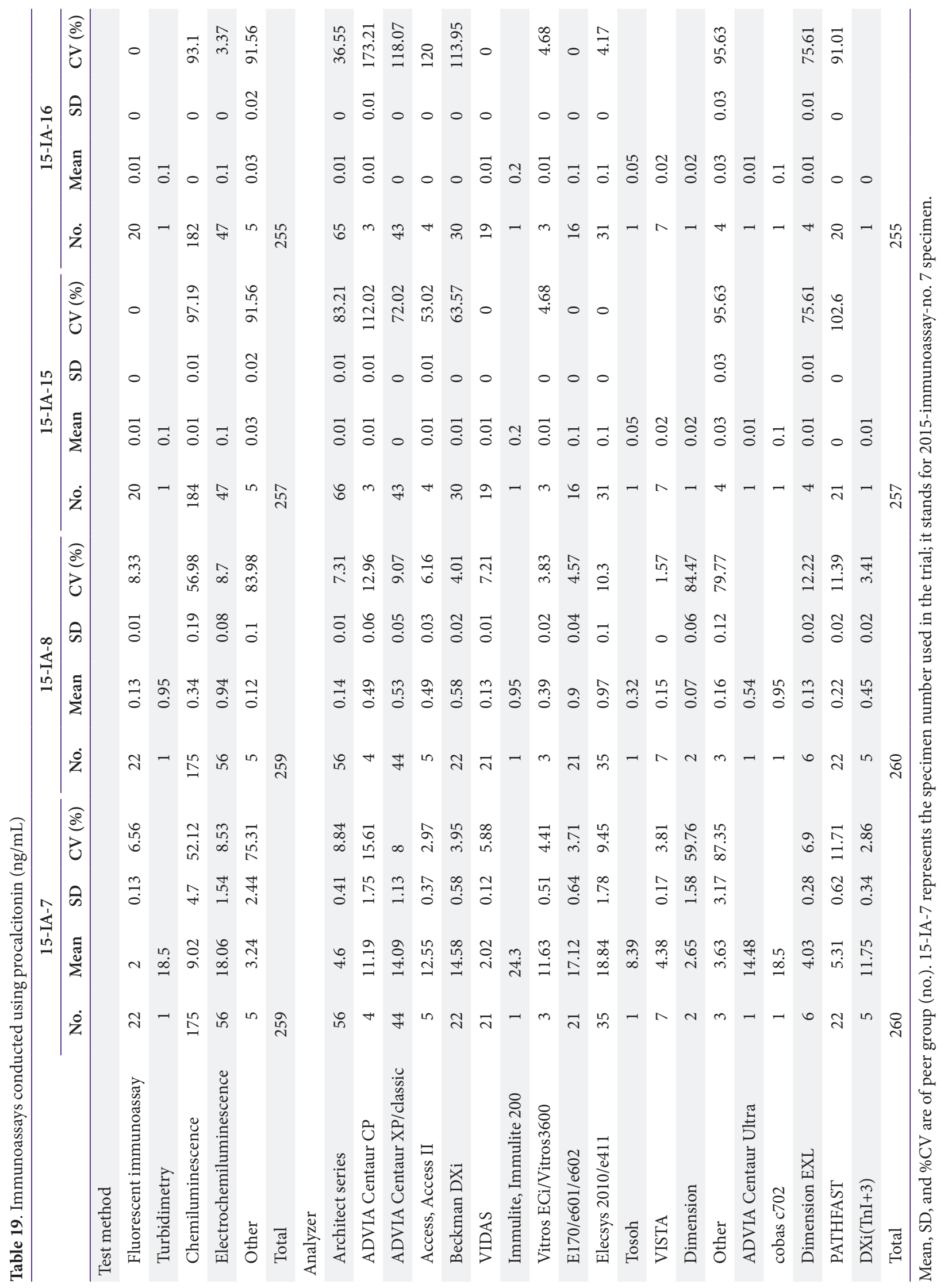


것은 권장되지 않지만 우리나라에서는 흔히 건강검진 등에 포 함되기 때문에 검사를 실시하는 기관 수가 많은 것으로 생각된 다. 특히 남성 종양표지자로 흔히 사용되는 PSA와 여성 종양 표지자로 볼 수 있는 CA 125 등을 실시하는 기관들을 살펴보 면, 이 종목들이 검진목적으로 사용되고 있는 것으로 생각되었 다. 참고로 이때 다른 여성 종양표지자라고 할 수 있는 $\mathrm{HCG}$ 나 $\beta-\mathrm{HCG}$ 를 실시하는 기관은 비교적 많지 않았다. 특히 장비 에 따라 $\beta-\mathrm{HCG}$ 가 아니라 $\mathrm{HCG}$ 로 측정하는 기관 수가 현저히 많아진 것으로 생각된다. 그리고 각 종양표지자 종목들의 통계 분석결과가 서로 다른 종양표지자 종목들이라도 비슷하였는 데, 그 이유는 각 기관에서 어떤 장비든지 동일한 자동면역분 석기를 이용하여 종양표지자검사들을 실시하기 때문에 장비 의 특성에 따라 비슷하게 나타난 것으로 생각되었다.

전년도에 이어 2015년도에도 과거 10여 년간 혈청면역단백 카테고리의 외부정도관리사업의 문제점을 보완하고자 새로 도입된 종목들을 시도하였다. 참여도가 높지 않은 CTX 대신 procalcitonin 등 새로운 염증 및 항균제 모니터링검사 등을 시 도하였다. Procalcitonin의 경우 심장표지자보다는 많이 실시 하지 않고 있었지만 골흡수표지자보다는 훨씬 많은 185 기관에 서 결과를 회신하였다.

아직도 각 기관에서 결과입력을 마친 후 그 입력된 전체결과 를 다시 검토하거나 확인하지 않기 때문에 생기는 것으로 생각 되는 사무 오류들이 역시 제일 많았다[12]. 단위까지 확인하는 정확한 결과 입력 등 좀더 세심하게 사무적 착오에 대해 확인 할 필요가 있을 것으로 생각된다. 따라서 아직도 결과분석 전 에 우리 분과 담당자들이 일일이 전화를 하여 확인할 필요가 있다는 것이 문제점으로 파악된다[13-15]. 각 회원기관들에서 외부정도관리물질로 검사를 실시하고 나서 그 결과를 인터넷 에 입력 또는 회신하기 전에 각 담당자 또는 책임자들이 재검 토하고 정확히 확인하여 각 기관의 결과를 입력/회신하여 준 다면 전체 결과 개선에 크게 도움이 될 것이다. 그리고 자신이 입력한 결과를 다시 한번 꼼꼼이 재확인하여 사무적 오차를 줄 일 수 있으면 정확하고 표준화된 외부정도관리사업이 가능할 것으로 생각된다[16-18].

2008년부터는 전체 병원의 통계는 우리 협회 홈페이지에 서 내려받거나 출력할 수 있게 되었으며, 따라서 보고서 송부 시에 두꺼운 전체 기관 통계자료를 같이 보내지 않게 되었고 각 기관에서도 필요할 때마다 인터넷에서 확인할 수 있다. 뿐 만 아니라 2010년부터는 각 기관의 결과지까지도 수시로 협회 인터넷 홈페이지에서 출력할 수 있도록 협회차원에서 전산화 가 구축되었기에 각 참여기관들도 훨씬 편리하고 수시로 확인 해 볼 수 있었다. 분과별 외부정도관리사업이 그동안 진행되면
서 참여기관들의 정도관리에 대한 인식이 많이 높아졌고, 무엇 보다 전국적인 검사결과 신뢰도에 대한 관심이 커졌다고 생각 된다. 특히 시약 제조/수입 회사나 장비 회사에서도 해당 장비 및 시약에 대한 유지 보수 및 정도관리에 대한 관심이 높아졌 다. 따라서 우리나라 임상검사실의 수준이 우리 협회의 외부정 도관리사업을 통해 진일보하고 있으며, 의료수준도 업그레이 드 되었다고 생각된다.

또 하나 사회적으로 비용효율을 중요시하는 트렌드를 읽을 수 있었는데, 즉 2015년도 2차에 참여기관이 730기관에 관리 물질을 보냈지만 693기관만이 회신해 옴으로써 1차의 710 기 관 회신보다도 다소 참여기관 수가 적어진 것이 눈에 띄었는 데, 이는 각 시도별 건강관리협회가 각 기관에서 검사실을 운 영하던 것을 통합 운영하게 되었기 때문인 것으로 밝혀졌다. 즉 제대로 검사실을 운영하는 것을 원칙으로 하되 효율적인 면 을 중시하여 필요한 경우 다른 검사실로 의뢰하는 것도 적극적 으로 고려하고 있음을 알 수 있었다.

\section{감사의 글}

본 Immunoassay 분과 외부정도관리사업을 위해서 자가제 조용 관리물질 검체를 농도별로 수집하고 우송, 안정성 검사과 정에서 헌신적으로 도와주신 연세의료원 진단검사의학과 교 직원 여러분과 우리 협회 Immunoassay 분과위원들께 깊이 감사드린다.

\section{Immunoassay 분과위원회 위원(2015)}

김현숙(위원장, 연세대학교 의과대학 세브란스병원), 김영 란(간사, 연세의료원 세브란스병원), 심정은(연세의료원 세브 란스병원), 임환섭(가톨릭관동대학교 의과대학), 원동일(경북 대학교병원), 박정용(연세의료원 세브란스병원), 정순호(연 세대학교 의과대학 강남세브란스병원), 장호은(분당서울대학 교병원), 임승택(서울아산병원), 조윤정(고려대학교 의과대학 안암병원), 남정현(인하대학병원)

\section{REFERENCES}

1. Kim HS, Kim YL; Immunoassay Subcommittee, Korean Association of External Quality Assessment Service. Annual report on external quality assessment scheme for immunoassay tests in Korea (2014). J Lab Med Qual Assur 2015;37:190-208. 


\section{Journal of LABORATORY MEDICINE and QUALITY ASSURANCE}

Hyon-Suk Kim et al • External Quality Assessment for Immunoassay Tests

2. Kim HS, Kim YL; Immunoassay Subcommittee, The Korean Association of Quality Assurance for Clinical Laboratories. Annual report on external quality assessment of immunoassay testing in Korea (2013). J Lab Med Qual Assur 2014;36:171-89.

3. Kim HS, Kim YL, Park J, Kwon OH, Kim DA, Kim JQ, et al. Immunoassay external quality assessment of immunoassay subcommittee (2010). J Lab Med Qual Assur 2011; 33(Suppl):S91-114.

4. Kim HS, Kim YL, Park J, Kwon OH, Kim DA, Kim JQ, et al. Annual report on external quality assessment in immunoassay in Korea (2009). J Lab Med Qual Assur 2010;32:103-14

5. Cha YJ, Kwon SY, Kim TY, Kim JR, Kim HS, Park MH, et al. Annual report on external quality assessment in immunoserology in Korea (2008). J Lab Med Qual Assur 2009;31:49-72.

6. Kim HS, Kim YL, Lim HS, Park J, Chun HS, Shin S, et al. Annual report on external quality assessment of Immunoassay Subcommittee in Korean Clinical Laboratory Survey (2007). J Lab Med Qual Assur 2008;30:11132.

7. Kim HS, Kim YL, Lim HS, Chun HS, Shin S, Jung YS, et al. Annual report on external quality assessment of Immunoassay Subcommittee in Korean Clinical Laboratory Survey (2006). J Lab Med Qual Assur 2007;29:99119.

8. Kim HS. Immunoassay external quality control of immunoassays. J Lab Med Qual Assur 2003;25(S2):S38791.

9. Kim HS, Lim HS, Kwon OH, Kim DA, Kim YK, Kim
YR, et al. Annual report on external quality assessment of immunoassay in Korea (2001). J Clin Pathol Qual Control 2002;24:83-94.

10. Kwon OH, Lim HS, Kim HS, Kim DA, Kim YK, Kim JQ, et al. Annual report on external quality assessment in immunoassay in Korea (2000). J Clin Pathol Qual Control 2001;23:111-44.

11. Kim HS. Future trends of immunoassay EQA. J Clin Pathol Qual Control 2001;23:S275-6.

12. Jenny RW, Jackson-Tarentino KY. Causes of unsatisfactory performance in proficiency testing. Clin Chem 2000; 46:89-99.

13. Kwon OH, Lim HS, Kim HS, Kim DU, Kim YK, Kim JQ, et al. Annual report on external quality assessment in immunoassay in Korea (1995). J Clin Pathol Qual Control 1996;18:95-117.

14. Kim HS. Internal quality control of immunochemistry tests. J Clin Pathol Qual Control 1993;15:S147-51.

15. Feldkamp CS, Carey JL. Standardization of immunoassay methodologies. In: Rose NR, Hamilton RG, Detrick B, editors. Manual of clinical laboratory immunology. 6th ed. Washington (DC): ASM Press, 2002:1215-26.

16. Bock JL. The new era of automated immunoassay. Am J Clin Pathol 2000;113:628-46.

17. College of American Pathologists. Standards for laboratory accreditation: Laboratory Accreditation Program 1998 edition. http://www.cap.org (Accessed December 2, 2015).

18. Miyai K, Price CP. Problems for improving performance in immunoassay. J Int Fed Clin Chem 1992;4:154-63. 
Immunoassay 분과 외부신빙도조사 결과보고(2015) 김현숙 • 김영란 • 심정은 • 대한임상검사정도관리협회 Immunoassay 분과위원회 연세대학교 의과대학 세브란스병원 진단검사의학과

2015년도 Immunoassay 분과에서는 2회에 걸쳐 각 8종씩, 총 16종의 관리물질을 1차 719기관, 2 차 730 기관에 보내어 외부신빙도조사를 실시하였다. 1회와 2 회째 모두 갑상선호르몬검사용 관리물 질과 심근표지자 troponin은 높은 결과치를 보이는 혈청을 수집하기 어려웠기 때문에 상품화된 제 품을 구입하여 사용하였고, 그 외의 관리물질은 자가제조하였다. 결과 회신율은 1차 $98.7 \%$ 와 2 차 $94.9 \%$ 였다. 검사결과의 분석 및 보고방법은 평균, 표준편차, 변이계수 등으로 분석하였으며, 참여기 관에서 사용하고 있는 방법과 장비에 따라 각 기기별로 분류하여 peer group 결과를 분석하였다. 협 회에 전산화가 잘 되어 있어서 우리 분과의 외부신빙도조사 결과 입력은 물론, 전체 방법과 기기별 통 계, 그리고 협회 홈페이지에서 인터넷을 이용하여 각 기관의 결과지 출력까지 할 수 있었다. 현재 참 여기관들에서 가장 많이 사용되는 면역측정법은 자동화된 화학발광면역장비들이었는데, 이들 자동화 장비들이 대개 고유원리와 시약을 사용하고 있어서 서로 결과치가 다를 수 있다. 따라서 정확한 결과 를 위해서는 장비와 사용자에 따른 내부정도관리뿐 아니라 외부정도관리가 지속적으로 필요한 것으 로 판단되었다. 또한 지금까지와 마찬가지로 전국적인 신빙도조사사업 참여를 통해 검사의 질을 높여 나가야 할 것으로 생각되었다.

(J Lab Med Qual Assur 2016;38:194-213)

교신저자: 김현숙

우)03722 서울시 서대문구 연세로 50-1, 연세대학교 의과대학 진단검사의학교실

Tel: 02)2228-2443, Fax: 02)364-1583, E-mail: kimhs54@yuhs.ac

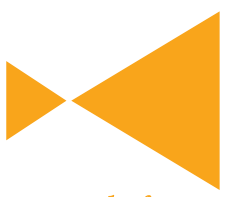

Journal of

LABORATORY MEDICINE and

QUALITY ASSURANCE 